\title{
Shopping to Get the Most for your Money ${ }^{1}$
}

Mary N. Harrison ${ }^{2}$

People must make choices about food, clothing, and housing as well as non-essentials. Our wants are endless, but our resources are not! To become a competent consumer, you must develop skills to serve you in a complex marketplace. When buying goods and services, if you spend your money wisely you will receive satisfaction and value for the dollars you spend. To become a competent consumer, learn to shop effectively.

\section{Know your Needs and Wants}

Know the difference between things you need and things you want. For example, you need protein in your diet, you may want steak.

Know which are long-range goals and which are immediate needs. Your long-range goal may be to save for a new car. Your immediate need may be to have dependable transportation to go to work. This could mean comparing the cost of repairing your car with the expense of trading it for a better one.

\section{Know your Requirements}

Individuals and families have different needs. For example, both you and your neighbor may need transportation. Your neighbor who has several children may need a four door, full size car to transport his family. Meanwhile you may live alone and often drive on long trips. For you a reliable, comfortable, fuel-efficient car would be a wise choice.

Before buying, determine why you want an item. What purpose will it serve? Do you want to "look as good or better than the neighbors?" Will the purchase help you feel important? Or, are you buying because the item is greatly reduced in price? Perhaps you feel it is "Such a good buy," you cant pass it up, even if you don't need it.

What is the intended use of the item? Will it do what you expect it to do? What are the trade offs? For example, if you are shopping for a car to be used to transport children to school, you will need seating space and 4 doors. If parking is a problem, a small car is easier to park. But, if your car is to be used as transportation for a large family, a compact car will be crowded. Which is a greater problem to you, limited parking space or an overcrowded car?

1. This document is Fact Sheet FCS 5008, a series of the Department of Family, Youth and Community Sciences, Florida Cooperative Extension Service, Institute of Food and Agricultural Sciences, University of Florida. Revised: June 2005. First published: June 1982. Please visit the EDIS Web site at http://edis ifas.ufl.edu

2. Written by Mary N. Harrison, professor, Consumer Education, and reviewed by Josephine Turner, CFP, professor, Family and Consumer Economics, Department of Family, Youth and Community Sciences, Cooperative Extension Service, Institute of Food and Agricultural Sciences, University Florida, Gainesville FL 32611.

The Institute of Food and Agricultural Sciences (IFAS) is an Equal Opportunity Institution authorized to provide research, educational information and other services only to individuals and institutions that function with non-discrimination with respect to race, creed, color, religion, age, disability, sex, sexual orientation, marital status, national origin, political opinions or affiliations. U.S. Department of Agriculture, Cooperative Extension Service, University of Florida, IFAS, Florida A. \& M. University Cooperative Extension Program, and Boards of County Commissioners Cooperating. Larry Arrington, Dean 


\section{Know your Resources and Decide the Amount to be Spent}

- Develop a family spending plan and involve all family members.

- List resources (income, etc.) available to be used for your family's needs and wants.

- Carefully plan the amount of money you'll need for necessities. Write down your fixed expenses, such as house payment or rent, car payment and insurance. Now add the monthly average of the other expenses such as utility bills, food, clothing, medical costs and other expenses. Total these. Subtract this total from your monthly income.

- Remember to save some money each month for emergencies and future needs. The equivalent of 3 to 9 months income should be available to meet unexpected emergencies.

- Compare your income with your expenses. Then decide the amount you can afford to spend for your wants.

- Rank your wants in order of importance. Consider alternatives in deciding the order.

\section{Plan Before your Buy}

- Thoughtful planning gives direction to all shopping decisions, also, it simplifies shopping.

- Consider carefully: small day-to-day expenses, purchase of durable goods, and expensive items.

\section{Get Reliable Information}

Sources of reliable information:

- County Extension faculty

- Government bulletins

- Consumer service booklets and magazines
Consider and Evaluate:

- Books

- Advertising

- Information from industry and mass media (TV, radio, newspapers, and magazines).

\section{Use Shopping Lists}

Develop lists for:

- Things you buy regularly.

- Things you buy occasionally.

Keep a list handy so that you can jot down items when you see you need them. Organize the list by kinds of items wanted and their locations in stores. Identify sizes, colors, or measurements when appropriate.

\section{Learn about Marketplaces}

- Know about the kinds of stores in the community, products or merchandise carried by, each kinds of services offered, and the advantages and disadvantages for each type of store.

- Business reputations of merchants. Shop only with reliable ones. No one store is the best place to shop at all times for all items.

\section{Choose the "Right" Shopping Time}

- Remember that the time of the week and year affect buying patterns, products offered, and prices.

- Learn to recognize the differences between sale items and "special purchases."

- Become familiar with the various types of sales:

- Inventory Sales, held just before stores take inventory to reduce merchandise inventory and taxes.

- Situational Sales, such as fire sales, going-out-of-business sales, moving sales, etc. 
- Seasonal Sales, for example, after Christmas sales, white sales in January and July, summer clearance and other special occasions.

- Promotional Sales, used to introduce a new product or a new market, to stimulate sales on a particular product, or to encourage buying when business is slow.

- Shop at the beginning of a sale for best selection.

- Shop for specific items that you plan to buy.

- Examine merchandise carefully to determine why it has not sold at regular price.

- Remember, no purchase is a bargain at any price if you don't need it!

\section{Look for and Compare Quality}

- Quality implies a standard of excellence which may or may not relate to price.

- Does the quality of the item relate to how well it will serve its purpose and intended use?

- Are there variations in the quality and cost of different brands? A higher price is not an assurance of a better quality.

- Most brands offer products of more than one quality.

Consider high quality if:

- An article is to be used over a long period of time or often.

- Fine detail in construction, workmanship, and styling are important.

Consider medium quality if:

- An article is expected to give reasonable service.

- Sturdy construction is important but not fine detail.

Consider low quality if:

- Items are bought for limited or short-term use.
- Appearance is relatively unimportant as long as the item serves its particular purpose.

\section{Make Price Comparisons}

- Compare prices of identical quality items by various brands and at different stores.

- Compare care that is required, the service or maintenance needed, and the warranties as well as price.

- Expect to pay a reasonable price. Avoid "bait advertisements" or "something-for-nothing-offers."

\section{Read Labels, Hangtags, and Warranties}

- Labels hangtags, and warranties provide information about products, their care, and their use.

- They may indicate the grade or quality.

- Warranties and guarantees list any services that are offered with the item, and the conditions and terms required.

- Keep a file for the warranties and hangtags. Use them for reference in the care, use, and service expectations.

\section{Learn About Legal Protections and Agencies Administrating them}

- Expect and demand that products measure up to quality and safety standards established by law.

- Report defects, poor quality, or performance to the seller and manufacturer.

- If you see violations of legal regulations, report them to the appropriate regulatory authorities.

\section{Know the Consumer's Responsibilities}

- Expect reasonable service from merchants and products.

- Return only products with which you have a legitimate complaint or for a justifiable reason. 
- If merchandise is to be returned or exchanged, do so promptly, unused, and in the original container, if there is one.

- Be honest in dealing with merchants.

- Pay bills on time.

- Do not abuse merchandise on display or misuse purchases.

Remember: An informed consumer is his own best protection. If you make wise choices, you'll get more satisfaction for dollars spent. Its up to you! An ounce of protection can save a heap of money. 